\title{
EFFECT OF SOME MAJOR ELEMENTS ON GROWTH PERFORMANCE AND BLOOD PARAMETERS IN FISH
}

\author{
Dena A. Abdel-Bary ${ }^{1 *}$, Khattab ${ }^{2}$ H.M., Amer ${ }^{2}$ M.A. and Hashim ${ }^{1}$ A.
}

1- Regional Center for Food and Feed, Agric. Research Center, Giza, Egypt

2- Animal Production Dept., Fac. of Agric., Ain Shams Univ., P.O. Box 68, Hadayek Shobra 11241, Cairo, Egypt

*Corresponding author: denaabbas81@yahoo.com

\section{ABSTRACT}

The present experiment was conducted to determine the optimal source and level of phosphorus supplementation in commercial feeds with the highest growth rate and the lowest releasing in environmental and protect water quality of Nile Juveniles tilapia (Oreochromis niloticus). Fish were divided into twelve groups (groups) each group was stocked into two aquaria each contains 10 fish.

Fish were fed diet contained different levels of phosphorus $(0.005,0.007,0.009$ and $0.011 \% \mathrm{Kg}$ diet phosphorus) from three different sources of phosphorus (mono calcium phosphate, mono potassium phosphate and mono sodium phosphate) for a period of 12 weeks. Results showed that average daily gain, specific growth rate, protein efficiency ratio and feed conversation ratio were significantly improved at $(p) 1.1 \%$ dietary phosphorus level with mono sodium phosphate as the source of phosphorus, mono calcium phosphate represented the highest significant $(P<0.05)$ value of growth and blood parameters (Packed cell volume (PCV), Hemoglobein( $\mathrm{Hb})$, red blood cell(RBC) and white blood cell(WBC) in Oreochromis niloticus .

Concerning levels of phosphorus the result clearly indicated that the $0.9 \%$ phosphorus level recorded the significant $(\mathrm{P}<0.05)$ highest growth and blood parameters in Oreochromis niloticus. Body composition analysis showed that the whole body protein and ash content were increased linearly but lipid was decreased $(P<0.05)$ with increasing dietary of phosphorus.
Keywords: Phosphorus requirement, Growth Rate, Blood Parameters, Nile Tilapia (Oreochromis niloticus)

\section{INTRODUCTION}

Phosphorus is one of the most important minerals for fish, it is essential for normal growth and bone mineralization, and plays an important role in the metabolism of carbohydrate, lipid and amino acids, as well as various metabolic processes involving buffering in body fluids (Watanabe et al 1988). The optimal amount of phosphorus supplementation in commercial feed is not only important economically, but also for environmental reasons to minimize its faecal and urinary discharge into natural waters (Bureau and Cho 1999).

Phosphorus is an essential element for both plant growth and animal performance. In the soil, phosphorus exists in different forms, associated with soil particles; in mineral form mostly as Fe-Al oxides or Calcium carbonates; incorporated in organic matter; and to a much lesser extent in soluble form dissolved in the soil solution. Phosphorus absorption capacity is the process in which soluble phosphorus is substituted for less soluble forms by reacting with inorganic or organic compounds of the soil so that it becomes immobilized. Phosphorus can move into surface waters and cause water quality problems such as eutrophication. In surface waters, phosphorus is often found to be the growth limiting nutrient. If excessive amounts of phosphorus and nitrogen enter the water, algae and aquatic plants can grow in large quantities. Cycles of algal 
blooms and periods of low dissolved oxygen concentrations can lead to fish kills (European Commission, DG Environment, 2005).

Phosphorus is an important constituent of nucleic acids and cell membranes, and is directly involved in all energy- producing cellular reactions. The role of phosphorus in carbohydrate, lipid, and amino acid metabolism, as well as in various metabolic processes involving buffers in body fluids, is also well established.

The aim of this study is estimating the optimum source and level for enhancing the growth performance, body composition and blood parameters of Tilapia Juvenile (Orechromis niloticus).

\section{MATERIALS AND METHODS}

The experiment was carried out at Regional Centre for Food and Feed, Minister of Agriculture, Egypt for a period of 3 months using Nile tilapia Juveniles (Oreochromis niloticus, $25 \mathrm{~g}$ average body weight).The experimental system was a separator system (open system), consisting of 24 fiber glass aquarium of 60 liter each $(60 \times 40 \times 25$ $\mathrm{cm}$ as length, width, depth). Each aquarium contained 10 Nile tilapia fish Juveniles (Oreochromis niloticus) of $25 \mathrm{~g}$ average body weight.

Twelve experimental diets belonging to three sources with four levels of phosphorus. Fish were divided into twelve groups each group was stocked into two aquaria(Triplicate) and each contains 10 fish, the diet contained $30 \%$ protein and $3848 \mathrm{kcal}$ energy/digestible energy. Fish were fed at $3 \%$ of live body weight feeding level for 12 weeks at the end of the experimental period all fish in each aquarium were killed.Chemical analysis of the experimental diets were carried out according to AOAC (2000). Fish were fed 0.005, 0.007, 0.009, $0.011 \% \mathrm{Kg}$ phosphorusdiets from three different sources (Mono basic potassium phosphate (KH2Po4), mono sodium phosphate (NaH2Po4.2H2O), mono calcium phosphate (ca (H2Po4)2).Formulation and chemical composition of the experimental diets are shown in Table (1).

Table 1. Formulation and chemical composition of the experimental diets (gm\1000gm diet)

\begin{tabular}{|l|c|c|c|c|c|c|c|c|c|c|c|c|}
\hline \multicolumn{1}{|c|}{ Ingredients } & \multicolumn{3}{c|}{$\begin{array}{c}\text { Mono basic potassium } \\
\text { phosphate (KH2Po4) }\end{array}$} & \multicolumn{3}{c|}{ mono sodium } \\
phosphate NaH2Po4.2H2O & \multicolumn{3}{c|}{ mono calcium } \\
phosphate (ca(H2Po4)2)
\end{tabular}

$1 \mathrm{NFE}=100-($ Moisture + Crude protein + Ether extract + Ash + crude Fiber). , 2 Digestible energy, based on 5.0 Kcal/g protein, 9.0 $\mathrm{Kcal} / \mathrm{g} \mathrm{lipid}$, and $2.0 \mathrm{Kcal} / \mathrm{g}$ carbohydrate (Wee and Shu, 1989) 
At the end of the experimental period (3months) 5 fish were randomly taken from each experimental group for blood analysis. Blood samples from each fish of the different groups were collected by suction of the caudal peduncle. Whole blood samples were collected in small plastic vials containing heparin for determination of hemoglobin $(\mathrm{Hb})$, packed cell volume (PCV), white blood cells (WBC) and red blood cell (RBC). The hemoglobin concentration was determined by using commercial kits (Elnasr Pharmaceutical Chemicals Co. Egypt) and the packed cell volume (PCV) was measured according to Stoskop (1993), The total counts of (RBC) and (WBC) were determined manually with a Neubauer Counting Chamber after the blood was diluted with Daice diluting Fluid Solution.

\section{Statistical analysis}

Statistical analysis was applied according to Steel and Torrie (1990) on the collected data using a SAS program (1998).Differences between means were tested for significance according to Duncan's Multiple Rang Test (Duncan, 1955).

\section{RESULTS AND DISCUSSION}

\section{1- Growth performance}

The results of Table (2) showed that mono sodium phosphate at $1.1 \%$ level represented the highest significant $(P<0.05)$ value of feed intake $(\mathrm{FI})$, weight gain (WG), average daily weight gain (ADWG), specific growth rate (SGR) and protein efficiency ratio (PER). With regard to sources of phosphorus the result (Table 2) exhibited that the highest significant $(P<0.05)$ feed intake $(F I)$, weight gain (WG), average daily gain (ADG), specific growth rate (SGR) and protein efficiency ratio (PER) was observed in mono calcium phosphate. Concerning levels of phosphorus the result clearly indicated that the $0.9 \%$ phosphorus level recorded the significant $(P<0.05)$ highest feed intake $(F I)$, weight gain (WG), average daily gain (ADG), specific growth rate (SGR) and protein efficiency ratio $(P E R)$. The significant $(P<0.05)$ best value of feed conversion ratio (FCR) was noticed for mono sodium phosphate at $1.1 \%$ level (2.34) and the significant $(\mathrm{P}<0.05)$ worst feed conversion ratio (3.63) was recorded for mono potassium phosphate at $1.1 \%$ level. With regard to the effect of source regardless level of phosphorus results showed that the significant $(\mathrm{P}<0.05)$ best $(F C R)$ value was noticed for mono calcium phosphate (2.54) and the worst value was observed for mono potassium phosphate (2.81). Concerning the effect of level regardless source of phosphorus the best significant $(\mathrm{P}<0.05)$ feed conversion ratio was observed with $0.9 \%$ level (2.39) whereas the significant $(P<0.05)$ worst one $(2.97)$ was noticed with $1.1 \%$ level.

The present results show that mono sodium phosphate at the level of $1.1 \%$ phosphorus significantly enhanced specific growth rate of Oreochromis niloticus fingerling compared with the other sources and levels of phosphorus. Lall S.P. (1991) reported that decrease dietary phosphorus under the minimum requirement level caused negative phosphorus balance and result of growth retardation and consequent economic losses, adjusted phosphorus balance will depend on dietary phosphorus supply, on its bioavailability in the different feedstuffs, and on the absorption rate. Effects of dietary phosphorus level on growth performance were reported in many fish species. Improved growth was observed in common carp (Hepher et al 1989) juvenile haddock (Roy K. et al 2003), juvenile silver perch (Yang et al 2006), and juvenile black sea bream (Hepher et al 1984). Nwanna, L.C. et al (2008) reported that the weight gain and specific growth rate (SGR) were increased steadily with increasing dietary phosphorus levels. Nordrum et al (1997) reported that the availability of phosphorus from added inorganic phosphorus-salts to fish is higher than from natural sources such as fishmeal and fish bone meal, depending on the solubility of the phosphorus-salt. The difference is probably due to fish species, form of phosphorus particularly relating to solubility, fish size, type of diet and culture system. 


\begin{tabular}{|c|c|c|c|c|c|c|c|c|c|c|c|c|}
\hline 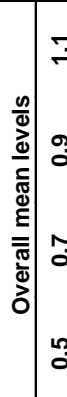 & 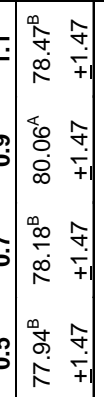 & & 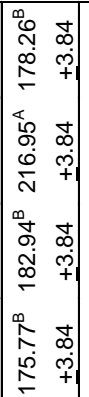 & & 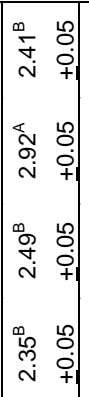 & & 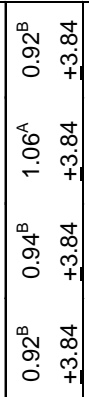 & & 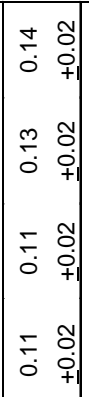 & & 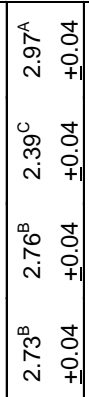 & \\
\hline 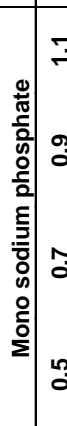 & 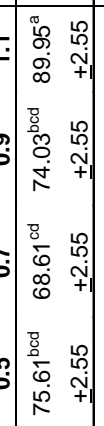 & 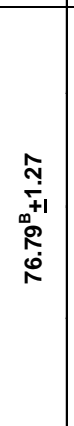 & 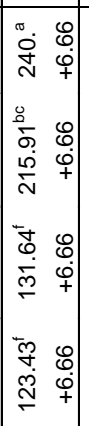 & 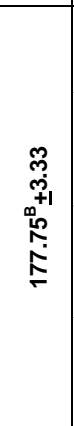 & 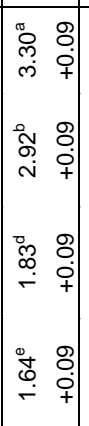 & 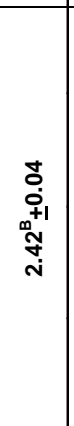 & 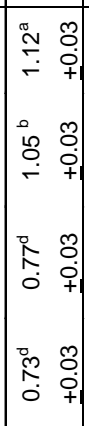 & 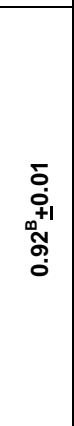 & 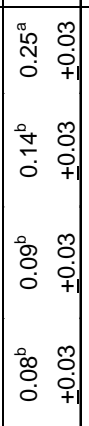 & 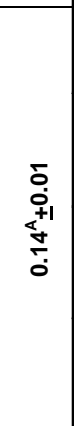 & 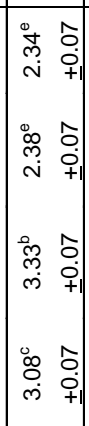 & 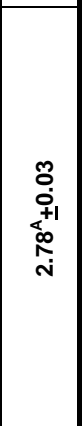 \\
\hline 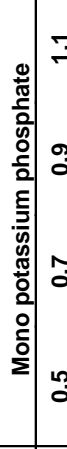 & 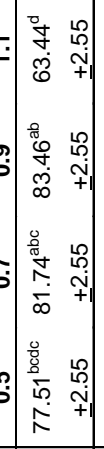 & $\begin{array}{c}\hat{N} \\
\stackrel{+}{+1} \\
\infty \\
\tilde{N} \\
\stackrel{\rho}{\rho}\end{array}$ & 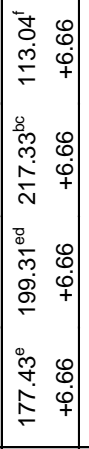 & 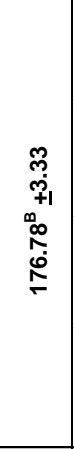 & 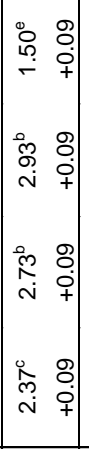 & 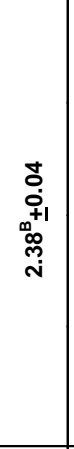 & 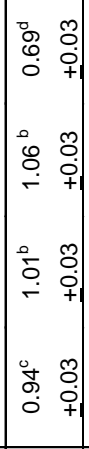 & 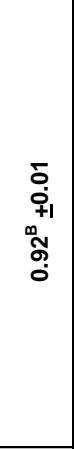 & 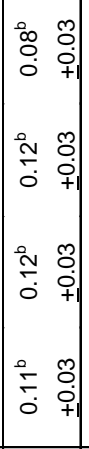 & $\begin{array}{c}\bar{j} \\
\dot{j} \\
\dot{+1} \\
\infty \\
\bar{\sigma} \\
0\end{array}$ & 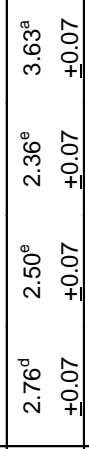 & 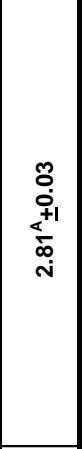 \\
\hline 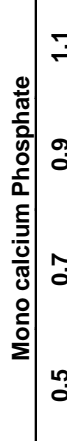 & 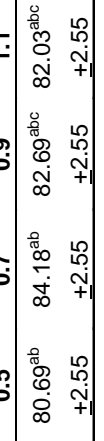 & 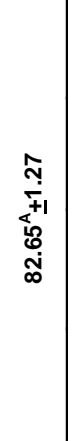 & 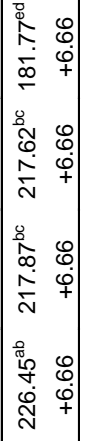 & 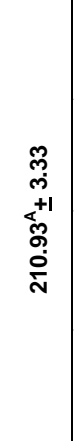 & 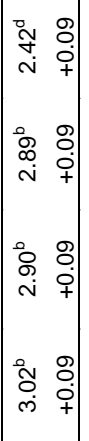 & 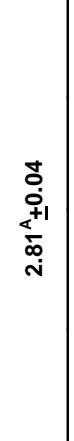 & 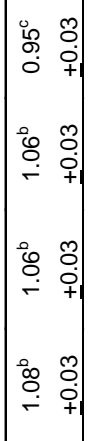 & 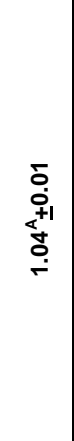 & 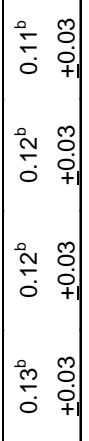 & 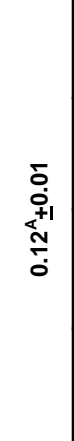 & 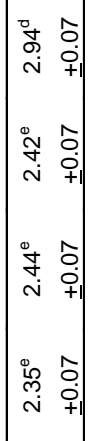 & 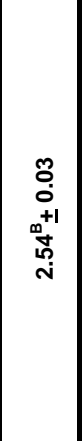 \\
\hline 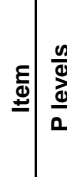 & 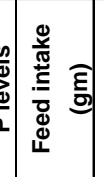 & 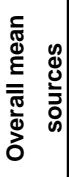 & $\begin{array}{l}\frac{\delta}{5} \\
\frac{5}{3}\end{array}$ & 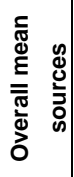 & 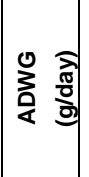 & 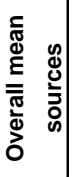 & 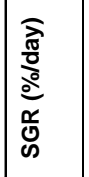 & 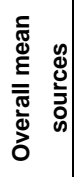 & 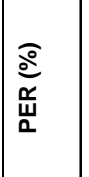 & 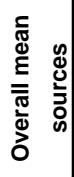 & 뜬 & 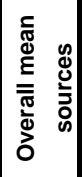 \\
\hline
\end{tabular}




\section{Chemical composition of Oreochromis nilot- icus}

The data of Table (3) showed that the significant $(\mathrm{P}<0.05)$ highest body protein content $(58.43 \%)$ was recorded for mono calcium phosphate at $0.9 \%$ phosphorus level whereas the lowest one $(44.53 \%)$ was detected for mono potassium phosphate at $0.5 \%$ phosphorus level. The highest significant $(\mathrm{P}<0.05)$ body lipid content $(1.81 \%)$ was recorded for mono sodium phosphate at $0.5 \%$ phosphorus level whereas the lowest one $(1.37 \%)$ was detected for monosodium phosphate at $0.9 \%$ phosphorus level .higher body ash content (27.0\%) was recorded for mono sodium phosphate at $1.1 \%$ phosphorus level .whereas lower one (19.9\%) was detected for mono calcium phosphate at $0.5 \%$ phosphorus level.

Concerning the effect of phosphorus source the results showed that the significant $(P<0.05)$ highest whole body protein content $(52.88 \%)$ was recorded for mono calcium phosphate as sources of phosphorus while the lowest one $(46.20 \%)$ was detected for mono potassium phosphate. and the significant $(\mathrm{P}<0.05)$ highest whole body lipid content (1.61\%) was recorded for mono potassium phosphate as a source of phosphorus, and the significant $(P<0.05)$ lowest one $(1.57 \%)$ was detected for mono calcium phosphate, and the significant $(\mathrm{P}<0.05)$ highest whole body ash content $(23.25 \%)$ was recorded for mono calcium phosphate as a source of phosphorus while the significant $(\mathrm{P}<0.05)$ lowest one $(21.36 \%)$ was detected for mono potassium phosphate. With regard to the effect of phosphorus level the highest significant $(\mathrm{P}<0.05)$ body protein content $(51.81 \%)$ was recorded for $0.9 \%$ phosphorus level whereas the significant $(\mathrm{P}<0.05)$ lowest one $(45.73 \%)$ was detected for $0.5 \%$ phosphorus level and the highest significant $(P<0.05)$ body lipid content $(1.74 \%)$ was recorded for $1.1 \%$ phosphorus level whereas the lowest one $(1.43 \%)$ was detected for $0.9 \%$ phosphorus level. The results clearly showed that as the level of phosphorus was increased, the body ash content of fish increased.

The highest body ash content (24.93\%) was recorded for the $1.1 \%$ phosphorus level whereas the significant $(P<0.05)$ lowest one $(20.27 \%)$ was detected for $0.5 \%$ phosphorus level.

Ogino et al (1979) and Robinson et al (1987). Showed that, the increasing of phosphorus content in the diet significantly altered the chemical composition content of protein and ash in carp, rainbow trout, and Nile tilapia. Bone ash content is consid- ered to be the most sensitive criterion for evaluating dietary phosphorus utilization. Skonberg et al (1997); Hardy et al (1991) and Skonberg et al (1997) showed that the carcass ash and carcass phosphorus have been generally used as indicators of dietary phosphorus position in fish nutrition researches because the role of phosphorus in the bone structure. Vielma et al (2002) showed that excess lipid accumulation due to phosphorus deficiency has been linked to changes in intermediate metabolism rather than in feed intake. Also Roy and Lall (2003) reported that insufficient phosphate might have inhibited esterification of the free fatty acid with extra-mitochondrial CoA to yield fatty acyl-CoA resulting in a lower utilization of lipid as an energy source. In addition the fat increasing of fish suffer from low $(0.5 \%)$ diet phosphorus(table3) may be attributed to the inhibition of B-oxidation of fatty acids resulting in a decrease utilization of Iipids as energy source and used the protein as the source of energy. The present results of fish lipid carcass content are in good agreement with those of Oliva-Teles and pimentet-rodrigues (2004), Zhang, et al (2006) who reported that the lipid content was decreased linearly with increasing dietary phosphorus.

\section{Effect of treatments on some blood parame- ters}

It is of interest to notice (Table 4) that mono sodium phosphate at $1.1 \%$ level recorded significant $(\mathrm{P}<0.05)$ highest value of packed cell volume PCV (32.05\%), hemoglobin $\mathrm{Hb}(8.93 \mathrm{mg} / \mathrm{dl})$, red blood cell RBC $\left(2.4210^{6} / \mu \mathrm{L}\right.$ ) and white blood cell WBC $(68544 \mu \mathrm{L})$.

The same treatment (mono sodium phosphate) showed at $0.5 \%$ level significant lowest values of PCV (28.500\%), Hb (7.3mg/dl), RBC (2.02 10\%/ L ) and WBC $(36586 \mu \mathrm{L})$.

With regard to the effect of phosphorus source the results mono calcium phosphate recorded the significant $(\mathrm{P}<0.05)$ highest value of $\mathrm{PCV}$ (30.82\%), Hb (8.44mg/dl), WBC $(61980 / \mu \mathrm{L})$ and nonsignificant $(P>0.05)$ highest value RBC (2.25 $\left.10^{6} / \mu \mathrm{L}\right)$. However, mono potassium phosphate showed the corresponding lowest values $(29.56 \%$, $8.25 \mathrm{mg} / \mathrm{dl}, 47403.25 / \mu \mathrm{L}$ and $2.2110^{6} / \mu \mathrm{L}$ ).

The present results of blood parameters are in good agreement with those of Chen et al (2003) who shown that deficient phosphorus in diets cause reduction in haemoglobin content and red blood cell. 


\begin{tabular}{|c|c|c|c|c|c|c|c|}
\hline 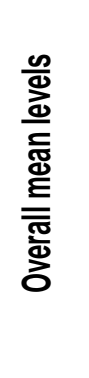 & $\begin{array}{l}= \\
8 \\
8 \\
0 \\
0 \\
0\end{array}$ & 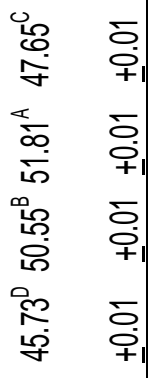 & & 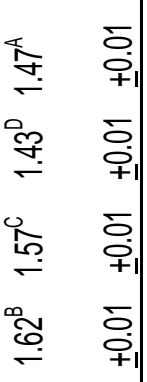 & & 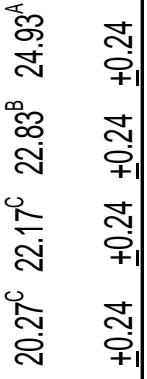 & \\
\hline 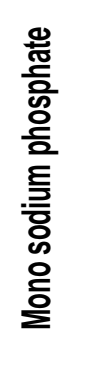 & 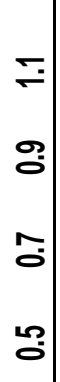 & 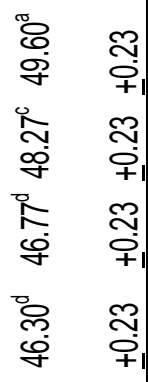 & 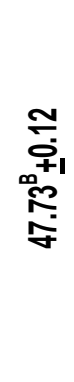 & 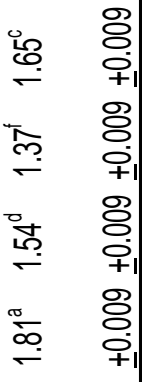 & $\begin{array}{c}\text { 농 } \\
\text { O } \\
\text { +1 } \\
\text { \% } \\
\stackrel{8}{\circ}\end{array}$ & 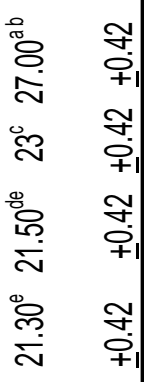 & 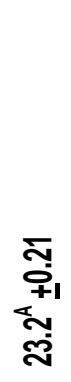 \\
\hline 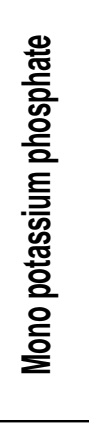 & 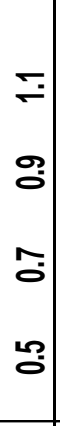 & 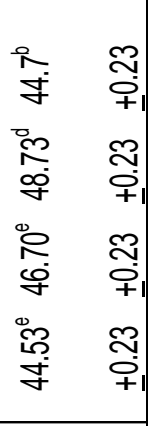 & 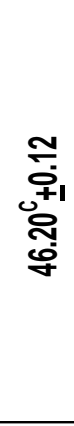 & 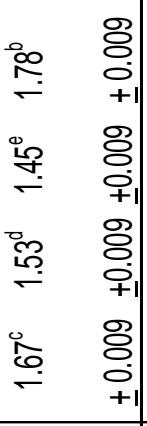 & 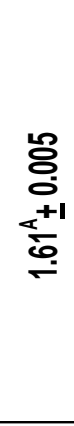 & 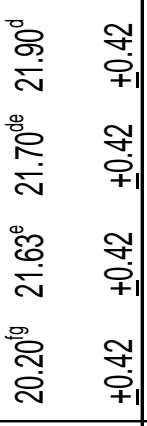 & 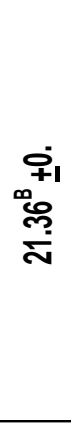 \\
\hline 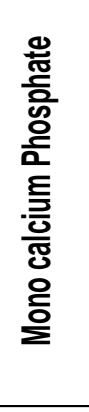 & 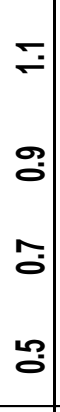 & 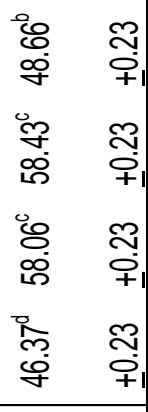 & 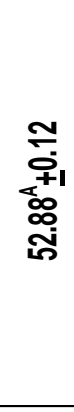 & 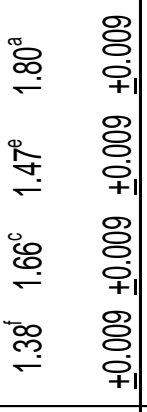 & 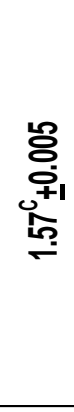 & 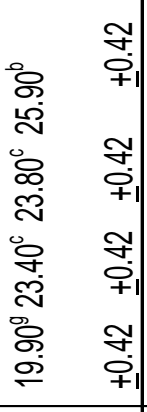 & 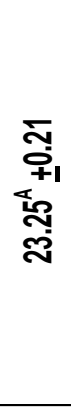 \\
\hline$\stackrel{\underline{\Xi}}{ \pm}$ & & 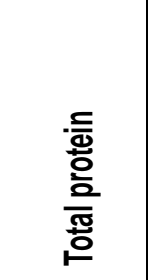 & 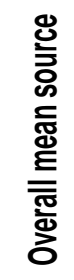 & $\begin{array}{l}\text { 을 } \\
\underline{\underline{\underline{\underline{I}}}} \\
\text { 용 }\end{array}$ & 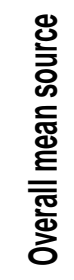 & 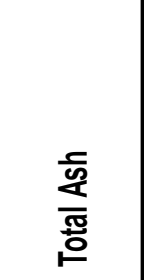 & 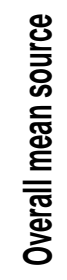 \\
\hline
\end{tabular}




\begin{tabular}{|c|c|c|c|c|c|c|c|c|}
\hline 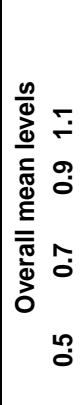 & 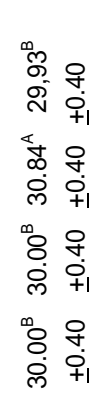 & & 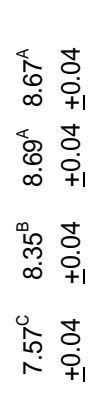 & & 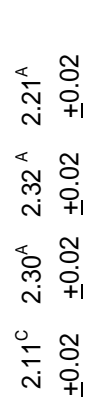 & & 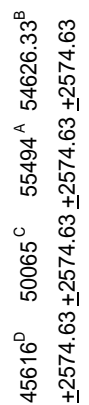 & \\
\hline 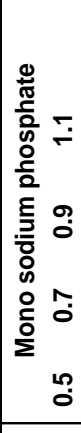 & 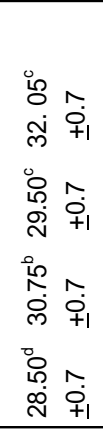 & 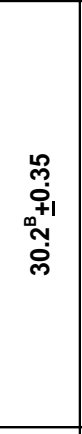 & 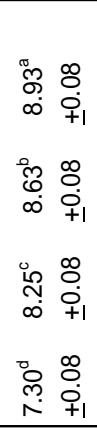 & 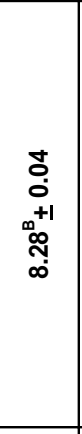 & 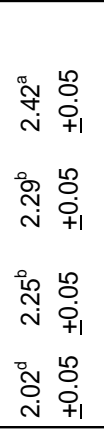 & 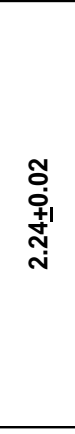 & 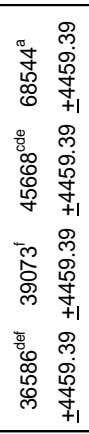 & 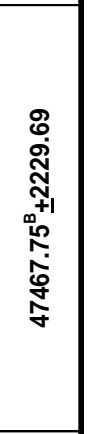 \\
\hline 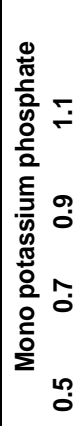 & 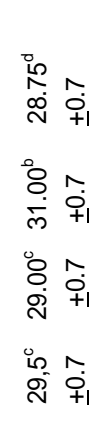 & 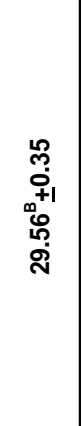 & 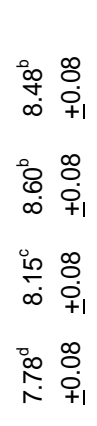 & 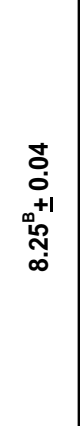 & 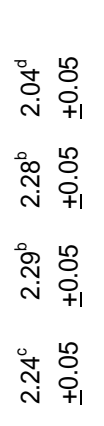 & $\begin{array}{l}\text { ̃ } \\
\dot{+} \\
\stackrel{+1}{N} \\
\text { N }\end{array}$ & 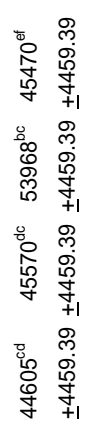 & 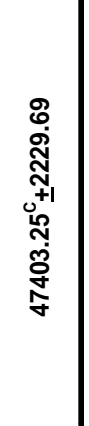 \\
\hline 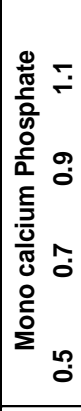 & 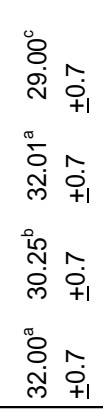 & 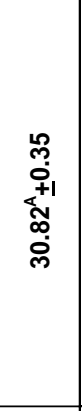 & 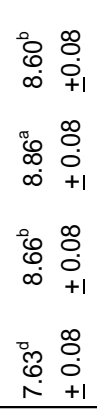 & $\begin{array}{l}\dot{J} \\
\dot{0} \\
+1 \\
+\neq \\
\dot{+} \\
\infty\end{array}$ & 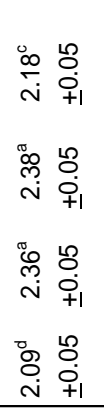 & 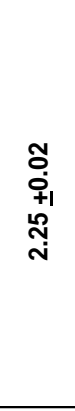 & 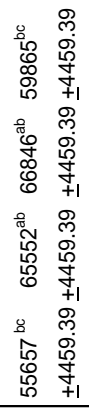 & 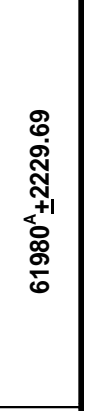 \\
\hline $\begin{array}{l}\mathbf{E} \\
\Phi \\
\Phi\end{array}$ & 仓̊ํㅁ & 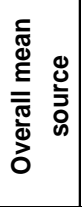 & 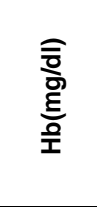 & 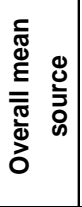 & 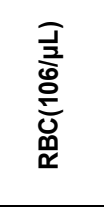 & 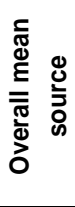 & 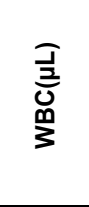 & 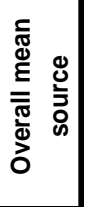 \\
\hline
\end{tabular}


Hematological and serological parameters are useful in monitoring the physiological status of fish and as indicators of the health of the aquatic environment, although they are not routinely used in fish disease diagnosis El-Sayed (1999). Terry et al (2000) reported that although tilapia is the second most frequently cultured fish in the world, there are a few reported of normal blood values. Adamu and Audu (2008) reported that decrease in (PCV) is attributed to gill damage or impaired osmoregulation causing anaemia and haemodilution.

Phosphorus and other minerals $(\mathrm{Na}, \mathrm{Ca}, \mathrm{K})$ in blood were perferring to estimate with blood parameters

\section{CONCLUSION}

In conclusion, the present study showed the mono calcium phosphate represented the highest significant $(\mathrm{P}<0.05)$ value of growth and blood parameters in Tilapia fish (Oreochromis niloticus). Concerning levels of phosphorus the result clearly indicated that the $0.9 \%$ phosphorus level recorded the significant $(\mathrm{P}<0.05)$ highest growth and blood parameters in Oreochromis niloticus.

\section{REFERENCE}

Adamu K.M. and Audu B.S. 2008. Hematological assessment of the Nile tilapia Oreochromis niloticus exposed to sublethal concentrations of Portland cement powder in solution. International J. of Zoological Research 4(1), 48-52.

AOAC. 2000. Association of Official Analytical Chemists international (AOAC) Official methods of analysis, (17 $7^{\text {th }} \mathrm{Ed}$.). AOAC International, Gaithersburg, MD, USA.

Bureau D.P. and Cho C.Y. 1999. Phosphorus utilization by rainbow trout Oncorhynchus mykiss estimation of dissolved phosphorus waste output Aquaculture, 179, 127-140.

Chen C.Y., Wooster G.A., Getchell R.G., Bowser P.R. and Timmons M.B. 2003. Blood chemistry of healthy nephrocalcinosis affected and ozone treated Tilapia in a recirculation System with application of discriminant analysis Aquaculture 218, 89-102.

Chunxiao Zhang, Kangsen Mai Qinghui Ai, Wenbing Zhang, Qingyuan Duan, Beiping Tan, Ma Hongming, Wei Xu, Zhiguo Liufu, Xiaojie Wang 2006. Dietary phosphorus requirement of juvenile Japanese seabass, Lateolabrax japonicus Aquaculture 255, 201-209.
Duncan D.B. 1955. Multiple Range and Multiple F tests Biometrics 11(1), 1-42.

El-Sayed A.F.M. 1999. Alternative dietary protein sources for farmed tilapia, Oreochromis spp. Aquaculture, 179, 149-168.

Hardy R.W., Fairgrieve W.T. and Scott T.M. 1991. Periodic feeding of low- phosphorus diet and phosphorus retention in rainbow trout Oncorhynchus mykiss., Fish Nutrition Practice., 61, 403-412.

Hepher B., Milstein A., Leventer H. and Telsch B. 1989. The effect of fish density and species combination on growth and utilization of natural food in ponds. Aquacult. Fish. Manage., 20, 59-71.

Hussein S.Y., El-Nasser M.A., Ahmed S.M. 1996. Comparative studies on the effect of the herbicide atrazine on freshwater fish Oreochromis niloticu and Chrysichthyes auratus at Assiut. Bull Environ Contam Toxicol., 57, 503-510.

Lall S.P. 1991. Digestibility, metabolism and excretion of dietary phosphorus in fish. Management of Aquaculture Waste. Fish Nutrition, pp. 2136.

Nordrum S., Asgard T., Shearer K.D., Arnessen P. 1997. Availability of phosphorus in fish bone meal and inorganic salts to Atlantic salmon (Salmosalar) as determined by retention. Aquaculture 157, 51-61.

Nwanna L.C., Kolahsa M., Eisenreich R., Schwarz F.J. 2008. Pre-treatment of dietary plant feedstuffs with phytase and its effects on growth and mineral concentration in common carp (Cyprinus carpio L.). J. Anim. Physiol. Anim. Nutr. 92, 677-682.

Ogino C., Takeuchi L., Takeda H. and Watanabe T. 1979. Availability of dietary phosphorus in carp and rainbow trout. Bull. Jpn. Soc. Sci. Fish., 45, 1527-1532.

Oliva-Teles A. and Pimentel-Rodrigues A. 2004. Phosphorus requirement of European sea bass (Dicentrarchus labrax L.) juveniles. Aquacult. Res., 35(7), 636-642.

Robinson E.H., La Bomascus D., Brown P.B. and Linton T.L. 1987. Dietary calcium and phosphorus requirements of Oreochromis aureus reared in calcium-free water. Aquaculture 64, 267-276.

Roy P.K. and Lall S.P. 2003. Dietary phosphorus requirement of juvenile haddock Melanogrammus aeglefinus $L$.. Aquaculture 221, 451-468.

SAS Institute Inc., 1998. SAS/STAT User's Guide Version 6.12. SAS Institute. Inc., North Carolina, USA. 
Skonberg D.L., Yoge L., Hardy R.W. and Dong F. 1997. Metabolic response of dietary phosphorus intake in rainbow trout (Oncorhynchus mykiss). Aquaculture, 157, 11-24.

Steel R.G.D. and Torrie J.H. 1990. Principles and Procedures of Statistics: with Special Reference to Biological Sciences. McGraw-Hill, USA, $481 \mathrm{p}$.

Terry C., Hrubec Jenifer L. and Smith Caradinale Stephen A. 2000. Hematology and plasma chemistry reference intervals forcultured Tilapia Oreochromis Hybrid. Vet Clin Pathal, 29(1), 7-12.
Vielma J., Koskela J. and Ruohonen K. 2002. Growth, bone mineralization and heat and low oxygen tolerance in European whitefish Coregonus lavaretus $L$. fed with graded levels of phosphorus. Aquaculture, 212, 321-333.

Watanabe, T., S. Satoh, and T., Takeuchi (1988) .Availability of minerals in fish meal to fish. Asian Fish. Sci., 1, 175-195.

Wee L. and Shu S.W. 1989. The nutritive value of boiled full-fat soybean in pelleted feed for Nile tilapia, Aquaculture 3, 303-314.

Yang, Y., Guo, Q., Huang J. and Fan Z. 2006. Study on phosphorus need on carp diet. J. Northeast Agric. Univ., 37, 48-51. 


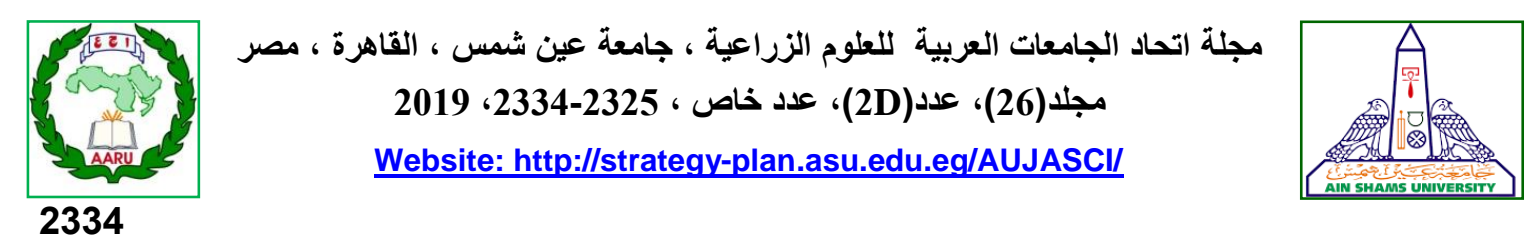

تاثير بعض العناصر الكبرى على اداء النمو ومقاييس الام فى الاسماك

[169]

$$
\begin{aligned}
& \text { دينا عباس عبد البارى1" - حمدى محمد خطاب22 - محمد عبد الباقي عامر2 - اشرف هاشم1 } 1
\end{aligned}
$$

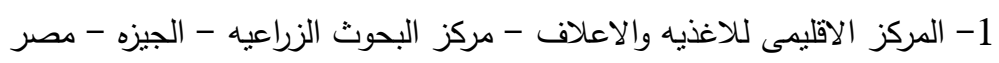

$$
\begin{aligned}
& \text { 2- قسم الانتاج الحيوانى - كليه الزراعه - جامعه عبن شمس - صلبع }
\end{aligned}
$$

*Corresponding author: denaabbas81@yahoo.com

Received 10 July, 2018

Accepted 30 July, 2018

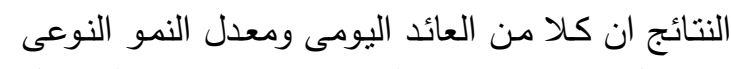

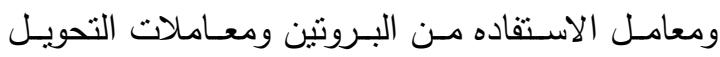

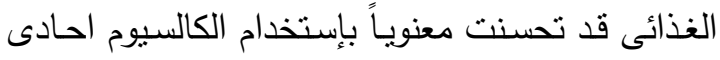

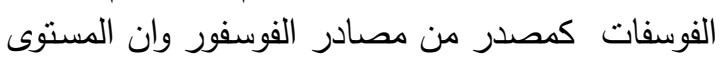

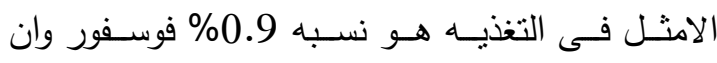

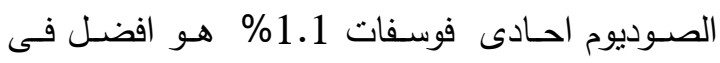

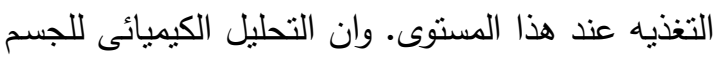

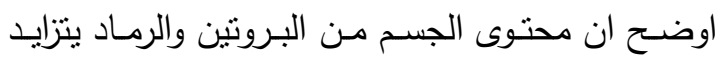

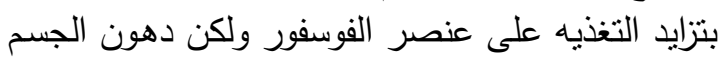
قد انخفضت بزياده التخذيه اليوميه للفوسفور •

الكلمات الداله: احتياجات الفوسفور، معدل النمو، النيات مقاييس الدم، البلطى النيلى الهيمات الني

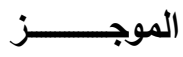

اجريت هذه الدراسـه لتقديرمصدر عنصر الفوسفور

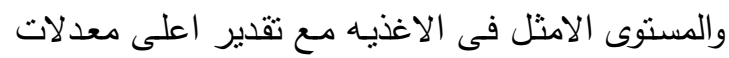
نمو واقل تحرر لعنصر الفوسفور في البيئه مـع حمايها

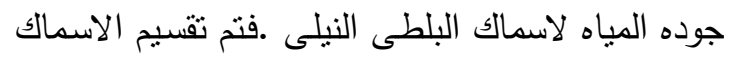

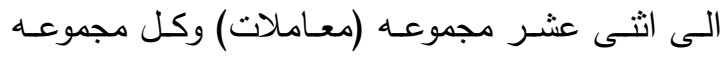

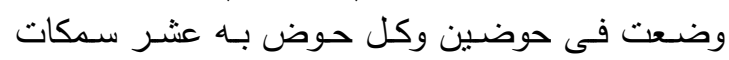
لمده 3 اثـهر مختلفه من عنصر الفوسفور (005\% 0.05\%، 0.007 \% \%

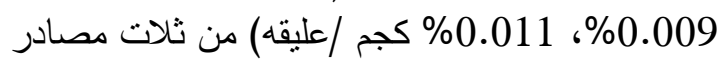

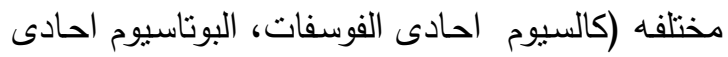

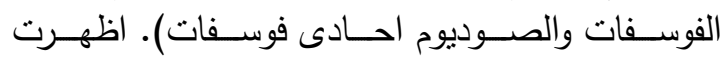

